\title{
PEMBERDAYAAN UMKM MELALUI PEMBIAYAAN \\ DENGAN PRINSIP BAGI HASIL OLEH LEMBAGA KEUANGAN SYARIAH
}

\author{
Rizki Tri Anugrah Bhakti \\ Fakultas hukum Universitas Putra Batam \\ J1. R. Soeprapto, Muka Kuning, Batam \\ Email: rizki.tri.ab@gmail.com
}

\begin{abstract}
This journal writing based on the ability of MSMEs to absorb labor in Indonesia which is quitelarge, as many as $97.3 \%$ of the total labor. The role of MSMEs due to have difficulties some factors, one of the factor is capital issues. To fact Syariah financial institution with the profit sharing principal to be expected become ideal solution. Based on those phenomenon it is necessary to some assessment on few point area, first: implementation of financing on Syariah financial institution in the Malang City related to the profit sharing principal which become ideal solutions for MSMEs. Second; some factors that become the barrier on implementation of Syariah financial institution in Malang City related to profit sharing principal and the Third; related some solutions to overcome the barrier factors on the implementation at Shariah financial institution in Malang City concerning exact profit sharing principal.
\end{abstract}

Key words: empowerment, micro small and medium enterprises (MSMEs), profit sharing, syariah financial institution

\begin{abstract}
Abstrak
Penulisan jurnal ini dilatarbelakangi kemampuan UMKM dalam menyerap tenaga kerja di Indonesia cukup besar, yaitu sebanyak $97,3 \%$ dari total angkatan kerja yang bekerja. Peran UMKM tersebut dalam kenyataannya terkendala oleh beberapa hal, diantaranya adalah permasalahan modal. Di sinilah lembaga keuangan syariah dengan pembiayaan berprinsip bagi hasil diharapkan menjadi solusi yang ideal. Mengamati fenomena yang demikian maka perlu dikaji mengenai beberapa hal, pertama pelaksanaan pembiayaan pada lembaga keuangan syariah di Kota Malang berkenaan dengan prinsip bagi hasil yang dirasa sangat ideal bagi UMKM. Kedua adalah berkenaan dengan faktor-faktor penghambat pelaksanaan pembiayaan pada lembaga keuangan syariah di Kota Malang berkenaan dengan prinsip bagi hasil, dan ketiga adalah berkaitan dengan solusi mengatasi faktor-faktor penghambat penghambat pelaksanaan pembiayaan pada lembaga keuangan syariah di Kota Malang berkenaan dengan prinsip bagi hasil yang dirasa sangat ideal tersebut.
\end{abstract}

Kata kunci: pemberdayaan, usaha mikro kecil dan menengah (UMKM), bagi hasil, lembaga keuangan syariah 


\section{Latar Belakang}

Kemampuan usaha mikro, kecil, dan menengah (yang selanjutnya disebut UMKM) dalam menyerap tenaga kerja di Indonesia cukup besar, yaitu sebanyak 97,3\% dari total angkatan kerja yang bekerja. ${ }^{1}$ Data Badan Pusat Statistik (BPS) mencatat jumlah UMKM di Indonesia tahun 2008 adalah lebih dari 51.000.000 (lima puluh satu juta) unit, dan merupakan unit usaha terbesar dari total unit usaha yang ada. Ini menandakan bahwa UMKM memiliki peran yang penting terutama dalam memperluas lapangan kerja, meningkatkan pendapatan masyarakat sehingga dapat menjadi penggerak pembangunan dan pertumbuhan ekonomi.

Keterbatasan modal merupakan permasalah yang umum dihadapi oleh UMKM, hal ini akan menyebabkan ruang gerak UMKM semakin sempit, ${ }^{2}$ misalnya mengalami kesulitan dalam mengembangkan usahanya dikarenakan tidak mampu memenuhi pesanan dari konsumen. Bila hal tersebut tidak teratasi maka dapat dimungkinkan usaha menciptakan lapangan pekerjaan akan kembali sulit diupayakan.

Lembaga keuangan syariah hadir sebagai wujud perkembangan aspirasi masyarakat yang menginginkan kegiatan perekonomian dengan berdasarkan prinsip syariah, selain lembaga keuangan konvensional yang telah berdiri selama ini. Lembaga keuangan syariah tersebut diantaranya adalah bank syariah dan Baitul Maal wat Tamwil (BMT) atau lembaga keuangan mikro syariah. Bila pada perbankan konvensional hanya terdapat satu prinsip yaitu bunga, maka pada lembaga keuangan syariah terdapat pilihan prinsip yang dapat disesuaikan dengan kebutuhan nasabah, yaitu prinsip bagi hasil, prinsip jual beli, prinsip sewa, dan prinsip jasa. Salah satu prinsip yang tepat diperuntukkan bagi pemberdayaan UMKM adalah prinsip bagi hasil. Secara umum prinsip bagi hasil dapat dilakukan dalam empat akad, yaitu mudharabah, musyarakah, muzara'ah, dan musaqah. Namun dalam praktiknya akad yang paling banyak dipakai adalah mudharabah dan musyarakah.

Pembiayaan dengan akad mudharabah dan musyarakah pada dasarnya merupakan pembiayaan yang sempurna, hal ini dikarenakan pada pembiayaan tersebut digunakan prinsip bagi hasil keuntungan (profit sharing). ${ }^{3}$ Selain menggunakan prinsip bagi hasil keuntungan (profit sharing), hal lain yang membuat ideal adalah adanya pembagian kerugian (loss sharing). Kerugian pada pembiayaan dengan akad mudharabah

1 Bank Indonesia, Buku Kajian Akademik Pemeringkat Kredit Bagi Usaha Mikro Kecil dan Menengah di

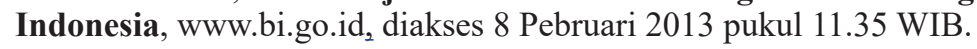

2 Suara Merdeka, 31 Desember 2012, Bank Syariah dan Industri Kreatif. Suara Merdeka, 8 November 2012, Pertumbuhan Perbankan Syariah Belum Optimal, Republika, 27 Oktober 2011, Pertumbuhan Perbankan Syariah Belum Optimal, Kompas, 3 Januari 2010, Keterbatasan UKM Dalam Meraih Pembiayaan Bank Syariah.

3 Burhanuddin S., Hukum Bisnis Syariah, UII Press, Yogyakarta, 2011, hlm. 125. 
akan ditanggung sepenuhnya oleh bank, kecuali bila nasabah melakukan kelalaian dan kesengajaan yang menyebabkan dialaminya kerugian. Kerugian pada pembiayaan dengan akad musyarakah akan dihitung sesuai dengan porsi modal masing-masing pihak, yaitu pihak bank dan nasabah. Pada dasarnya dengan prinsip bagi kerugian (loss sharing) ini, maka kedua pihak yaitu pihak nasabah dan pihak bank akan berusaha untuk menghindari terjadinya kerugian tersebut.

Pada pembiayaan mudharabah, bank bertindak sebagai shahibul maal yang menyediakan dana secara penuh dan nasabah bertindak sebagai mudharib yang mengelola dana dalam kegiatan usaha. Pembiayaan mudharabah ini memiliki karakter yang berbeda dengan kredit yang diberikan oleh bank konvensional, karakter tersebut adalah adanya keadilan dan kebersamaan yang merupakan semangat dari perbankan syariah. Hal ini dapat terlihat dari pembagian keuntungan dan kerugian di antara bank dengan nasabah pengelola dana. Keuntungan akan dibagi sesuai dengan kesepakatan yang tertuang dalam akad, sedangkan kerugian akan ditanggung oleh bank kecuali jika pihak nasabah pengelola dana melakukan kesalahan yang disengaja, lalai atau menyalahi perjanjian. Pada pembiayaan musyarakah maka terjadi percampuran dana antara dua pihak atau lebih untuk melakukan usaha tertentu yang halal dan produktif dengan kesepakatan bahwa keuntungan akan dibagi sesuai dengan nisbah yang disepakati dan risiko akan ditanggung sesuai porsi kerjasama.

Prosentase pemberian pembiayaan dengan prinsip bagi hasil, baik mudharabah maupun musyarakah dalam praktiknya masih lebih kecil bila dibandingkan dengan pembiayaan lain yang juga ditawarkan oleh perbankan syariah. Misalnya saja bila dibandingkan dengan pembiayaan murabahah yaitu pembiayaan dengan prinsip jual beli. Pada pembiayaan murabahah bank menyediakan dana atau tagihan untuk transaksi jual beli barang sebesar harga pokok ditambah margin atau keuntungan berdasarkan kesepakatan dengan nasabah.

Kecilnya porsi pembiayaan dengan prinsip bagi hasil muncul disebabkan karena beberapa persoalan, misalnya pembiayaan dengan prinsip bagi hasil sangat berisiko dan membutuhkan transparansi informasi juga kepercayaan tinggi antara pemilik modal (shahibul maal) dan pengelola usaha (mudarib), usaha mikro kecil sering dianggap sebagai unit usaha yang oleh perbankan sering disebut sebagai unit usaha yang tidak bankable, kebijakan perbankan itu sendiri, hingga perilaku masyarakat yang kurang menempatkan faktor kejujuran ketika mendapatkan pembiayaan dengan prinsip bagi hasil.

Kota Malang dengan penduduk yang bukan hanya dihuni oleh penduduk asli namun juga pendatang, memiliki potensi yang sangat baik terhadap perkembangan $\mathrm{UMKM}^{4}{ }^{4}$ Tercatat

4 Data statistik Dinas Koperasi dan Usaha kecil dan Menengah Kota Malang Tahun 2011. 
untuk jenis usaha handycraft, fashion dan makanan yang potensial sebagai oleh-oleh, jumlah UMKM adalah lebih kurang 63.000. Di sinilah lembaga keuangan syariah diharapkan perannya mengingat perkembangan jumlah UMKM di kota Malang yang semakin bertambah. Terlebih dengan adanya kebijakan perbankan, berkaitan dengan adanya Peraturan Bank Indonesia Nomor 14/22/ PBI/2012 tentang Pemberian Kredit atau Pembiayaan Oleh Bank Umum dan Bantuan Teknis Dalam Rangka Pengembangan Usaha Mikro Kecil dan Menengah. Pada Peraturan Bank Indonesia ini telah dengan jelas disebutkan bahwa bank umum termasuk bank syariah wajib memberikan kredit atau pembiayaan kepada UMKM dengan jumlah kredit atau pembiayaan ditetapkan paling rendah $20 \%$ (dua puluh persen) dari total kredit atau pembiayaan yang dilakukan, serta hadirnya undang-undang yang khusus menaungi lembaga keuangan mikro yaitu Undang-undang Nomor 1 Tahun 2013 tentang Lembaga Keuangan Mikro, seperti halnya Baitul Maal wat Tamwil (BMT).

\section{Pembahasan}

Lembaga keuangan (financial institutions) adalah suatu perusahaan yang usahanya bergerak di bidang jasa keuangan. ${ }^{5}$ Ini berarti bahwa kegiatan yang dilakukan oleh lembaga ini akan selalu berkaitan dengan bidang keuangan, berupa penghimpunan dana, menyalurkan, dan/atau jasa-jasa keuangan lainnya. Lembaga ini memiliki fungsi sangat penting, terutama sebagai lembaga intermediasi diantara para pemilik modal dengan pihak lain yang membutuhkannya. Selain lembaga keuangan yang telah ada, maka dalam perkembangannya hadir pula lembaga keuangan yang dalam menjalankan usahanya berdasarnya prinsip syariah, disebut sebagai Lembaga Keuangan Syariah. Kehadiran lembaga keuangan inilah yang memfasilitasi arus peredaran uang, sehingga uang dari masyarakat dapat dikumpulkan melalui berbagai bentuk produk penghimpunan dana sebelum disalurkan kembali kepada pihak yang membutuhkan dalam bentuk pembiayaan, baik yang bersifat sosial maupun bisnis.

Lembaga keuangan syariah pada penelitian ini difokuskan pada perbankan syariah dan Baitul Maal wat Tamwil (BMT). Menurut Ensiklopedi Islam, Bank Islam atau Bank Syari'ah adalah lembaga keuangan yang usaha pokoknya memberikan kredit dan jasa-jasa dalam lalu lintas pembayaran serta peredaran uang yang pengoperasiannya sesuai dengan prinsip-prinsip syari'ah. ${ }^{6}$ Berbeda dengan Baitul Maal wat Tamwil (BMT) yaitu suatu lembaga yang terdiri dari dua istilah, yaitu baitul maal dan baitul tamwil. ${ }^{7}$ Baitul maal lebih mengarah pada

5 Kasmir, Bank dan Lembaga Keuangan Lainnya, Rajawali Press, Jakarta, 1998, hlm. 2.

6 Warkum Sumitro, Asas-asas Perbankan Islam dan Lembaga-lembaga yang Terkait, RajaGrafindo, Jakarta, 1996, hlm. 5.

7 Nurul Huda dan Mohamad Heykal, Lembaga Keuangan Islam: Tinjauan Teoritis dan Praktis, Kencana, Jakarta, 2010, hlm. 363. 
usaha-usaha penghimpunan dan penyaluran dana yang non profit, seperti zakat, infaq dan shodaqoh. Adapun baitul tamwil sebagai usaha penghimpunan dan penyaluran dana komersial. Dahulu BMT merupakan salah satu unit usaha pada sebuah koperasi yang menginginkan salah satu unit usaha adalah jasa keuangan mikro dengan berprinsip syariah. Saat ini dengan hadirnya Undangundang Nomor 1 tahun 2013 tentang Lembaga Keuangan Mikro, maka BMT dapat berdiri sendiri dengan badan hukum berbentuk koperasi.

BMT juga merupakan lembaga ekonomi rakyat kecil yang berupaya mengembangkan usaha-usaha produktif dan investasi dalam rangka meningkatkan kegiatan ekonomi pengusaha kecil dengan berdasarkan prinsip syariah dan prinsip koperasi. ${ }^{8}$

Pendirian bank syariah dengan prinsip bagi hasil sudah sejak lama dicita-citakan oleh umat Islam di Indonesia. Hal itu terungkap dalam keputusan Majelis Tarjih Muhammadiyah yang diadakan di Sidoarjo, Jawa Timur pada tahun 1968. Dalam poin Nomor 4 diputuskan, Majelis Tarjih menyarankan kepada Pimpinan Pusat Muhammadiyah untuk mengusahakan terwujudnya konsepsi sistem perekonomian, khususnya lembaga perbankan yang sesuai dengan kaidah Islam. ${ }^{9}$

Kaidah Islam yang dimaksud di atas adalah adanya ketentuan hukum bahwa riba merupakan sesuatu yang telah diharamkan sehingga dilarang oleh agama. Keberadaan perbankan konvensional dengan sistem bunga merupakan bentuk riba, sehingga kemudian timbul pemikiran mendirikan bank syariah yang bertujuan untuk menjauhkan umat dari praktik riba dalam kegiatan usaha perbankan.

Pelarangan riba telah diatur secara tegas di dalam Al-Qur'an, yaitu Surat Al-Baqarah ayat 275,276 , dan 278. Sebagaimana telah diketahui bahwa kaidah hukum asal dalam syariah adalah ibadah dan muamalah. Ketika suatu transaksi baru muncul dan belum dikenal sebelumnya dalam hukum Islam, maka transaksi tersebut dianggap dapat diterima, kecuali terdapat implikasi dari dalil Al-Qur'an dan Al-Hadist yang melarangnya, baik secara eksplisit maupun implisit. Jadi dalam bidang muamalah semua transaksi dibolehkan kecuali yang diharamkan.

Adanya pembedaan antara bank umum yang kemudian dikenal sebagai bank umum konvensional dengan bank syariah adalah pembedaan menurut kegiatan usahanya. Bank umum konvensional melaksanakan kegiatan usahanya secara konvensional, sedangkan bank syariah melaksanakan kegiatan usahanya dengan berdasarkan prinsip syariah. ${ }^{10}$ Pada bank konvensional sesuai dengan Undangundang Nomor 7 Tahun 1992 sebagaimana telah diubah dengan Undang-undang Nomor 10 Tahun 1998 tentang Perbankan juga

8 Ahmad Hasan Ridwan, BMT dan Bank Islam Instrumen Lembaga Keuangan Syari`ah, Pustaka Bani Quraisy, Bandung, 2004, hlm. 5.

9 Suhrawardi K. Lubis, Hukum Ekonomi Islam, Sinar Grafika, Jakarta, 2004, hlm. 47.

10 Djoni S. Gazali dan Rachmadi Usman, Hukum Perbankan, Sinar Grafika, Jakarta, 2012, hlm. 153-155. 
diperbolehkan untuk melakukan dual banking system, yaitu di samping melaksanakan kegiatan usaha secara konvensional juga diperbolehkan membentuk Unit Usaha Syariah (UUS) yang dalam kegiatan usahanya berdasarkan prinsip syariah. Sebaliknya pada perbankan syariah terdapat larangan untuk melakukan kegiatan usaha secara konvensional.

Fungsi utama perbankan seperti menerima deposit, memberikan kredit atau pembiayaan berdasarkan prinsip syariah dan melakukan jasa transfer keuangan, dan lain-lain merupakan bagian yang tidak terpisahkan dari kehidupan umat Islam. ${ }^{11}$ Di dalam sejarah perekonomian umat Islam, pembiayaan yang dilakukan dengan akad yang sesuai syariah telah menjadi bagian dari tradisi umat Islam sejak zaman Rasulullah SAW. Bentuk akad seperti menerima titipan, meminjamkan uang dan pembiayaan usaha, serta melakukan berbagai akad terkait dengan jasa keuangan sudah merupakan bagian dari kehidupan muamalat saat itu.

Kegiatan penyaluran dana dalam bentuk pembiayaan dengan prinsip bagi hasil merupakan perwujudan nilai dasar dari sistem hukum ekonomi Islam, yaitu kerja sama antara pemilik modal atau uang dengan pengusaha yang mempunyai keahlian, keterampilan atau tenaga dalam melaksanakan unit-unit ekonomi atau usaha. ${ }^{12}$ Prinsip bagi hasil secara umum dapat dilakukan dalam 4 (empat) akad, yaitu musyarakah, mudharabah, muzara'ah, dan musaqah. Pada praktiknya, perbankan syariah lebih banyak memakai akad musyarakah dan mudharabah. ${ }^{13}$

Bentuk pembiayaan yang diharapkan mampu memberikan pemerataan kesejahteraan masyarakat adalah pembiayaan mudharabah dan musyarakah dengan prinsip bagi hasil (profit sharing). ${ }^{14}$ Mudharabah merupakan skema yang paling mendasar dalam memobilisasi sumber-sumber dana yaitu penggabungan antara pemilik dana dan pihak lain yang memiliki keterampilan menjalankan usaha. ${ }^{15}$ Pembiayaan mudharabah memiliki filosofi yaitu menyatukan modal (capital) dengan tenaga kerja (skill dan entrepreneurship). Hal inilah yang tidak ditemukan pada sistem perbankan konvensional. ${ }^{16}$ Pada pembiayaan mudharabah bank bertindak sebagai shahibul maal yang menyediakan dana secara penuh dan nasabah bertindak sebagai mudharib yang mengelola dana dalam kegiatan usaha, oleh karenanya maka pembiayaan mudharabah ini sangat bermanfaat untuk memenuhi

11 Adiwarman A. Karim, Bank Islam: Analisa Fikih dan Keuangan, RajaGrafindo Persada, Jakarta, 2004, hlm. 18.

12 A.M. Saefuddin, Studi Sistem Ekonomi Islam, Media Dakwah, Jakarta, 1984, hlm. 19-105.

13 Muhammad Syafi'i Antonio, Bank Syariah: dari Teori ke Praktik, Gema Insani Press, Jakarta, 2001, hlm. 85.

14 Burhanuddin S, Op.cit.

15 Hirsanuddin, Hukum Perbankan Syariah di Indonesia, Genta Press, Yogyakarta, 2008, hlm. 121.

16 Suhrawardi K. Lubis dan Farid Wajdi, Hukum Ekonomi Islam, Sinar Grafika, Jakarta, 2012, hlm. 57. 
kebutuhan permodalan usaha nasabah. Musyarakah adalah akad kerjasama atau percampuran antara dua pihak atau lebih untuk melakukan usaha tertentu yang halal dan produktif dengan kesepakatan bahwa keuntungan akan dibagi sesuai dengan nisbah yang disepakati dan risiko akan ditanggung sesuai porsi kerjasama. ${ }^{17}$ Pada pembiayaan musyarakah bank sebagai shahibul maal memenuhi sebagian modal suatu usaha mudharib berdasarkan persetujuan atau kesepakatan. Bank dan mudharib masingmasing bertindak sebagai mitra usaha, mudharib bertindak sebagai pengelola usaha dan bank sebagai mitra usaha dapat ikut serta dalam pengelolaan usaha sesuai dengan tugas dan kewenangan yang disepakati.

Dikeluarkannya Undang-undang Nomor 7 tahun 1992 sebagaimana diubah dengan Undang-undang Nomor 10 Tahun 1998 tentang Perbankan, Undang-undang Nomor 21 Tahun 2008 tentang Perbankan Syariah, serta adanya Undang-undang Nomor 1 Tahun 2013 tentang Lembaga Keuangan Mikro, membuka peluang dibukanya lembaga keuangan yang dioperasikan berdasarkan pada prinsip-prinsip Syari'ah, diantaranya perbankan syariah dan BMT. Dalam kegiatan operasionalnya, baik bank syariah maupun BMT memiliki kebijaksanaan yang berbeda-beda baik dalam hal penghimpunan dana maupun penyaluran dana.

Penyaluran dana oleh lembaga keuangan syariah dikenal dengan sebutan pembiayaan, berbeda dengan penyaluran dana oleh lembaga keuangan konvensional yang dikenal dengan sebutan kredit. Pada lembaga keuangan syariah, ketentuan pembiayaan juga memiliki kebijaksanaan yang berbeda-beda, bervariasi dan tergantung pada kebutuhan di masyarakat.

Penelitian menunjukkan bahwa tidak semua lembaga keuangan syariah di Kota Malang menerapkan pembiayaan dengan prinsip bagi hasil. Beberapa lembaga keuangan syariah bahkan menggunakan prinsip jual beli yaitu murabahah, padahal sebagaimana diketahui bahwa prinsip murabahah menerapkan margin keuntungan yang berarti bahwa bank meyakini bahwa usaha tersebut akan mendapatkan keuntungan juga. Hal ini berbeda dengan prinsip bagi hasil yang memperhitungkan adanya kemungkinan terjadinya impas atau tidak didapatnya keuntungan, bahkan terjadi kerugian. Pada prinsip bagi hasil, diyakini bahwa mudharib tidak mungkin berkeinginan untuk mendapatkan kerugian, baik kerugian tenaga, waktu, serta kesempatan untuk memperbesar usahanya sehingga keuntungan yang didapat juga semakin besar.

Penelitian juga menunjukkan bahwa walaupun bank sebagai salah satu lembaga keuangan telah menerapkan prinsip bagi hasil, namun dengan diterapkannya akad musyarakah dalam memberikan pembiayaan kepada UMKM, maka berarti bank hanya bersifat memberikan tambahan modal saja atas suatu usaha yang sudah berjalan, belum 
memberikan bantuan modal kepada nasabah yang memiliki kemampuan dan keterampilan namun tidak memiliki modal untuk memulai usaha. Sebagaimana diketahui bahwa UMKM diMalang bukan hanya yang bergerak dibidang industri yang membutuhkan bantuan modal, namun dengan besarnya jumlah penduduk maka yang berpotensi untuk diberdayakan juga adalah para pedagang kaki lima, misalnya saja penjual makanan, minuman, kebutuhan pokok, dan lain sebagainya.

Pemberian pembiayaan dengan prinsip bagi hasil kepada UMKM menggunakan prosedur umum pembiayaan, mulai dari pengajuan, analisis kelayakan, pembuatan akad (perjanjian), dan pengawasan. Pengajuan disertai dengan penyertaan dokumendokumen yang diperlukan, terlebih karena pemberian pembiayaan adalah kepada suatu badan hukum. Selanjutnya dilakukan analisis kelayakan usaha, dalam hal ini bank akan menerapkan prinsip 5'Cs yaitu: Character (penilaian watak/kepribadian), Chapacity (penilaian kemampuan), Capital (penilaian modal), Condition of Economy (penilaian terhadap keadaan pasar), dan Collateral (penilaian jaminan). Selain prinsip $5^{\prime} \mathrm{Cs}$, terdapat juga prinsip lain yang digunakan dalam melakukan analisa kelayakan, yaitu: Party, Purpose, Payment, Profitability, Protection. Ada juga prinsip 3R, yaitu: Returns, Repayment, serta Risk Bearing Ability.

Bentuk antisipasi agar tidak terjadi permasalahan di kemudian hari (macet), maka bank meminta calon debitur menyediakan jaminan berupa agunan yang nilainya minimal sebesar jumlah kredit atau pembiayaan yang diberikan kepadanya. Jaminan ini biasanya berupa sertifikat hak kepemilikan tanah dan bangunan serta hak kepemilikan kendaraan bermotor.

Setelah melakukan analisis menggunakan prinsip 5'Cs di atas dan diputuskan bahwa nasabah tersebut layak untuk diberikan pembiayaan, maka bank akan membuat suatu akad (perjanjian). Akad pembiayaan harus dibuat tertulis dengan memperhatikan rukun dan syarat-syarat sesuai dengan hukum Islam.

Prosedur umum pengajuan pembiayaan mulai dari pengajuan permohonan hingga pengawasan oleh bank, merupakan upaya bagi bank dalam menghindari risiko kemacetan. Sebagaimana dikatakan oleh Sutan Remy Sjahdeini bahwa setiap kredit atau pembiayaan berdasarkan prinsip syariah yang akan disalurkan pada nasabah tidak akan lepas dari tahapan proses pemberian kredit atau pembiayaan berdasarkan prinsip syariah, tahapan tersebut antara lain: (a) Tahap sebelum pemberian kredit atau pembiayaan berdasarkan prinsip syariah diputuskan oleh bank, yaitu tahap bank mempertimbangkan permohonan kredit atau pembiayaan berdasarkan prinsip syariah calon debitur, ini disebut tahap analisa kredit. (b) Tahap setelah kredit atau pembiayaan berdasarkan prinsip syariah diputuskan pemberiannya oleh bank dan kemudian penuangan keputusan ke dalam perjanjian kredit atau 
pembiayaan berdasarkan prinsip syariah serta dilaksanakannya pengikatan agunan untuk kredit atau pembiayaan berdasarkan prinsip syariah yang diberikan ini. Tahap ini disebut tahap dokumentasi kredit. (c) Tahap setelah perjanjian kredit atau pembiayaan berdasarkan prinsip syariah ditandatangani oleh kedua belah pihak dan dokumentasi pengikatan agunan kredit atau pembiayaan berdasarkan prinsip syariah telah selesai dibuat serta selama kredit atau pembiayaan berdasarkan prinsip syariah itu digunakan oleh nasabah debitur sampai jangka waktu kredit atau pembiayaan berdasarkan prinsip syariah belum berakhir. Tahap ini disebut tahap pengawasan dan pengamanan kredit atau pembiayaan berdasarkan prinsip syariah. (d) Tahap setelah kredit atau pembiayaan berdasarkan prinsip syariah bermasalah yaitu tahapan penyelamatan dan penagihan kredit atau pembiayaan berdasarkan prinsip syariah. $^{18}$

Tahap pertama sampai tahap ketiga adalah tahap preventif atau tahap pencegahan bagi bank agar kredit atau pembiayaan berdasarkan prinsip syariah tidak jadi bermasalah, sedangkan tahap keempat adalah tahap represif setelah kredit atau pembiayaan berdasarkan prinsip syariah bermasalah.

Kecilnya porsi pembiayaan oleh lembaga keuangan syariah dengan prinsip bagi hasil karena dihadapkan pada beberapa faktor. Instrument yang digunakan dalam menemukan faktor penghambat tersebut adalah instrument penilaian efektifitas hukum, yaitu: (a) hukum atau peraturan itu sendiri (substansi hukum), (b) mentalitas petugas yang menegakkan (struktur hukum), (c) fasilitas yang diharapkan untuk mendukung pelaksanaan hukum, (d) kesadaran hukum dan budaya masyarakat (budaya hukum). Melalui instrument penilaian di atas, maka dapat diketahui faktor-faktor penghambat tersebut tersebut antara lain: Pertama, hukum atau peraturan itu sendiri (substansi hukum), antara lain pelaksanaan prinsip kehati-hatian (prudential principle) yang diberlakukan perbankan. Prinsip ini membuat bank konvensional maupun bank syariah melakukan kegiatan usaha menghimpun dana dari masyarakat dan menyalurkannya kembali kepada masyarakat bertindak secara hati-hati, cermat, teliti dan bijaksana guna meminimalisir kemungkinan risiko yang kesemuanya adalah dalam rangka memberikan perlindungan terhadap dana masyarakat yang dipercayakan kepada lembaga perbankan, terlebih pada produk pembiayaan dengan prinsip bagi hasil yang bisa digunakan oleh UMKM dalam mengatasi permasalahan modal bagi usahanya, memiliki risiko yang tinggi, yaitu diantaranya side streaming, yaitu nasabah menggunakan dana tersebut bukan seperti dalam kontrak, lalai dan kesalahan yang disengaja, penyembunyian keuntungan oleh nasabah bila nasabahnya tidak jujur.

Wujud kehati-hatian perbankan dikenal 
dengan prinsip 5'Cs. Analisis di atas dipergunakan oleh bank konvensional maupun bank syariah sebelum kredit dikucurkan, sehingga memberikan keyakinan kepada bank bahwa proyek yang akan dibiayai dengan kredit bank cukup layak (feasible). ${ }^{19}$

Prinsip kehati-hatian menimbulkan dua kondisi yaitu, pertama, collateral oriented (berorientasi pada agunan). Prinsip ini sebenarnya merupakan prinsip yang ada pada Undang-undang Nomor 14 tahun 1967 tentang Pokok-Pokok Perbankan yang saat ini sudah tidak berlaku lagi. Berdasarkan ketentuan pasal tersebut, pemberian kredit hanya akan dilakukan oleh bank bila sebelumnya nasabah debitur menyediakan jaminan. Bank dilarang untuk memberikan kredit jika tidak disertai dengan jaminan karena jaminan merupakan syarat utama agar pemberian kredit dicairkan. Jaminan yang dimaksud disini adalah berupa jaminan kebendaan, yang dinamakan dengan agunan.

Undang-undang Nomor 7 Tahun 1992 sebagaimana diubah dengan Undang-undang Nomor 10 tahun 2008 tentang Perbankan, tidak lagi menggunakan prinsip tersebut, bahkan pada dasarnya ingin mengubah orientasi bank dan ingin memberikan kelonggaran kepada nasabah dalam hubungannya dengan kesulitan nasabah untuk dapat menyerahkan agunan. Bagi usaha mikro kecil khususnya, kewajiban adanya jaminan tersebut tentu akan sangat memberatkan, hal tersebut dapat dipahami mengingat usaha mikro kecil berdiri dengan modal yang tidak besar dan terbatas, bahkan hanya berbekal keahlian dan keterampilan serta tekad yang besar karena melihat adanya peluang untuk berkembang.

Bila memperhatikan Undang-undang Nomor 7 Tahun 1992 sebagaimana diubah dengan Undang-undang Nomor 10 tahun 2008 tentang Perbankan maka terdapat dua istilah yang memiliki perbedaan arti, yaitu istilah jaminan dan agunan. Pasal 8 ayat 1 Undangundang Nomor 7 Tahun 1992 sebagaimana diubah dengan Undang-undang Nomor 10 tahun 2008 tentang Perbankan menyatakan:

"Dalam memberikan kredit atau pembiayaan berdasarkan prinsip syariah, bank umum wajib mempunyai keyakinan berdasarkan analisis yang mendalam atas itikad dan kemampuan serta kesanggupan nasabah debitur untuk melunasi utangnya atau mengembalikan pembiayaan dimaksud sesuai dengan yang diperjanjikan.”

Penjelasan atas Pasal 8 ayat 1 Undangundang Nomor 7 Tahun 1992 sebagaimana diubah dengan Undang-undang Nomor 10 tahun 2008 tentang Perbankan menyatakan:

"Untuk mengurangi risiko tersebut, jaminan pemberian kredit atau pembiayaan berdasarkan prinsip syariah dalam arti keyakinan atas

19 Lukman Dendawijaya, Manajemen Perbankan, Ghalia Indonesia, Bogor, 2003, hlm. 91. 
kemampuan dan kesanggupan nasabah debitur untuk melunasi kewajibannya sesuai dengan diperjanjikan merupakan faktor penting yang harus diperhatikan oleh bank. Untuk memperoleh keyakinan tersebut, sebelum memberikan kredit, bank harus melakukan penilaian yang saksama terhadap watak, kemampuan, modal, agunan dan prospek usaha dari nasabah debitur. Mengingat bahwa agunan sebagai salah satu unsur pemberian kredit, maka apabila berdasarkan unsur-unsur lain telah diperoleh keyakinan, agunan dapat hanya berupa barang, proyek, atau hak tagih yang dibiayai dengan kredit yang bersangkutan"

Ketentuan tersebut bila dihubungkan dengan Penjelasannya menunjukkan bahwa makna kata jaminan tidak sama dengan makna kata agunan. Agunan hanyalah salah satu unsur dalam pemberian kredit, sedangkan jaminan berwujud keyakinan atas kemampuan dan kesanggupan nasabah debitur untuk melunasi kewajibannya sesuai dengan yang diperjanjikan, namun dalam praktiknya, yang dimaksud jaminan pemberian kredit atau pembiayaan berdasarkan prinsip syariah adalah agunan, dalam hal ini pada umumnya berwujud benda tertentu yang bernilai ekonomis guna dipakai sebagai pelunasan kredit atau pembiayaan berdasarkan prinsip syariah jika nasabah debitur wanprestasi.
Orientasi bank selama ini adalah mewajibkan atau menjadi keharusan tersedianya agunan atas kredit atau pembiayaan berdasarkan prinsip syariah. Padahal kewajiban adanya agunan tidak tercantum dalam Undang-undang Perbankan.

Kedua, mentalitas petugas yang menegakkan (struktur hukum) yaitu membuka peluang untuk bank membuat suatu self regulatory banking, yang berisi tentang ketentuan intern bank dalam menjalankan usahanya, walaupun tetap tidak diperbolehkan menyalahi ketentuan yang telah ditetapkan Bank Indonesia. Adanya self regulatory banking tersebut tentu akan membuka peluang untuk bank dengan bebas membuat aturan sesuai dengan keinginannya sendiri tanpa memperhatikan bahwa ada pihak-pihak yang mungkin tidak memiliki kemampuan yang sama.

Adanya kemampuan yang tidak sama tersebut di atas misalnya saja dalam hal adanya jaminan. Jaminan di dalam hukum Islam dibagi menjadi dua, yaitu jaminan yang berupa orang (personal guaranty) dan jaminan yang berupa harta benda. Jaminan yang berupa orang dalam Islam disebut dengan kafalah, sedangkan jaminan yang berupa harta benda dalam Islam disebut dengan rahn.

Keberadaan jaminan (agunan) bagi pembiayaan bagi hasil yang memang telah diakui oleh Majelis Ulama Indonesia. Untuk pembiayaan musyarakah diakui berdasarkan Fatwa Dewan Syariah Nasional No: 08/ DSN-MUI/IV/2000 tentang Pembiayaan 
Musyarakah. Pada angka 3 dinyatakan bahwa pada prinsipnya dalam pembiayaan musyarakah tidak ada jaminan, namun untuk menghindari terjadinya penyimpangan, Lembaga Keuangan Syariah dapat meminta jaminan. Sedangkan untuk pembiayaan mudharabah diakui berdasarkan Fatwa Dewan Syariah Nasional No: 07/DSN-MUI/ IV/2000 tentang Pembiayaan Mudharabah (Qiradh). Pada angka 7 dinyatakan bahwa pada prinsipnya, dalam pembiayaan mudharabah tidak ada jaminan, namun agar mudharib tidak melakukan penyimpangan, Lembaga Keuangan Syariah dapat meminta jaminan dari mudharib atau pihak ketiga. Jaminan ini hanya dapat dicairkan apabila mudharib terbukti melakukan pelanggaran terhadap hal-hal yang telah disepakati bersama dalam akad.

Hadirnya Peraturan Bank Indonesia Nomor 14/22/PBI/2012 tentang Pemberian Kredit atau Pembiayaan Oleh Bank Umum dan Bantuan Teknis Dalam Rangka Pengembangan Usaha Mikro Kecil dan Menengah (UMKM), yang dalam Pasal 2 menyebutkan bahwa bank umum wajib memberikan kredit atau pembiayaan kepada UMKM dengan jumlah kredit atau pembiayaan ditetapkan paling rendah 20\% (dua puluh persen) yang dihitung berdasarkan rasio kredit atau pembiayaan UMKM terhadap total kredit atau pembiayaan, seharusnya akan mampu meningkatkan jumlah pembiayaan khususnya bagi UMKM di Kota Malang. Terlebih di dalam Undangundang Nomor 20 Tahun 2008 tentang Usaha
Mikro Kecil dan Menengah juga menyebutkan bahwa Pemerintah menumbuhkan iklim usaha dengan menetapkan peraturan perundangundangan dan kebijakan yang salah satunya meliputi aspek pendanaan guna membantu para pelaku UMKM untuk mendapatkan pembiayaan dan jasa/produk keuangan lainnya yang disediakan oleh perbankan dan lembaga keuangan bukan bank, baik yang menggunakan sistem konvensional maupun syariah dengan jaminan yang disediakan pemerintah.

Ketiga, fasilitas yang diharapkan untuk mendukung pelaksanaan hukum, yaitu Sumber Daya Insani (SDI) juga menjadi permasalahan tersendiri bagi pihak bank. Terlebih sistem perbankan syariah di Indonesia masih belum lama dikenal, sehingga lembaga akademik dan pelatihan masih sangat terbatas. Hal ini menyebabkan tenaga terdidik dan berpengalaman di bidang perbankan syariah kurang memadai, padahal keberhasilan pengembangan bank syariah terutama dalam hal pengembangan UMKM sangat ditentukan oleh kualitas manajemen dan tingkat pengetahuan serta keterampilan pengelola bank. Selain SDI yang belum memadai, faktor lain yang menjadi kendala adalah pengembangan jaringan kantor bank syariah. Hal tersebut diperlukan dalam rangka perluasan jangkauan pelayanan kepada masyarakat. Sebagaimana diketahui bahwa UMKM merupakan unit usaha yang tersebar hingga ke pelosok daerah, bukan hanya berada di tengah kota. Kurangnya jumlah 
bank syariah hingga ke pelosok daerah sangat berbeda dengan jaringan bank konvensional yang jangkauannya sangat luas. Hal ini tentu berpengaruh terhadap kompetisi kualitas pelayanan dan inovasi produk perbankan syariah itu sendiri. Dari hasil penelitian menunjukkan bahwa selain kredibilitas, maka kualitas pelayanan juga mempengaruhi pilihan masyarakat untuk bergabung pada suatu bank.

Keempat, kesadaran hukum dan budaya masyarakat (budaya hukum), yaitu bahwa UMKM kurang menyadari pentingnya menjadi unit usaha yang bankable. Usaha yang bankable disini adalah usaha yang layak untuk dibiayai. Beberapa kriteria untuk menjadi usaha yang bankable antara lain usaha tersebut berbadan hukum, memiliki NPWP (Nomor Pokok Wajib Pajak), memiliki pencatatan keuangan yang baik (termasuk di dalamnya invoice, tagihan, kwitansi, serta semua kertas atau dokumen yang berhubungan dengan usaha), serta memiliki asset (bisa berupa mesin, kendaraan, tanah). Penelitian menemukan bahwa untuk menjadi usaha yang bankable, kesadaran tersebut masih sangat minim di masyarakat. Hal inilah yang kemudian membuat bank tidak secara langsung memberikan pembiayaan kepada UMKM, melainkan pemberian modal usaha tersebut secara tidak langsung baik dengan pola executing maupun pola chanelling kepada koperasi atau lembaga keuangan mikro syariah yang ada. Hal tersebut disebabkan karena bank tidak menginginkan risiko yang tinggi atas pembiayaan yang diberikannya. Selain itu faktor kejujuran juga menjadi penghambat. Pada dasarnya hanya mudharib (pengelola usaha) saja yang mengetahui secara pasti kondisi usahanya. Inilah yang kemudian menimbulkan suatu kondisi yang disebut dengan asymmetric information, yaitu kondisi dimana salah satu pihak menguasai informasi lebih baik dibandingkan dengan pihak lainnya, atau salah satu pihak tidak memiliki informasi yang sama dengan pihak lainnya. Bank sepenuhnya mempercayakan pengelolaan dananya kepada mudharib, termasuk mempercayakan laporan keuntungan ataupun laporan kerugian. Bila mudharib menjunjung tinggi nilai kejujuran, maka mudharib tidak melakukan manipulasi data keuangan. Kemungkinan terjadinya asymmetric information inilah yang kemudian menjadikan pembiayaan dengan prinsip bagi hasilyang seharusnya menjadi produk unggulan pada perbankan syariah saat ini hanya merupakan sebagian kecil saja dari seluruh pembiayaan yang ada. ${ }^{20}$

Faktor-faktor penghambat di atas sebenarnya dapat diatasi dengan mengupayakan beberapa hal, antara lain: pertama, perbaikan peraturan perbankan yaitu perlu disesuaikan agar bank dapat tetap dalam kondisi kesehatan yang baik dengan menerapkan prinsip kehati-hatian, namun tetap memperhatikan kondisi nasabah 
yang tidak selalu sama. Misalnya dalam hal pembebanan jaminan yang terasa sangat memberatkan UMKM yang terbatas terutama dalam hal asset.

Kedua, bagi UMKM yang terkendala dengan jaminan, maka dapat menjadi anggota pada suatu koperasi primer. Perbankan syariah dapat melakukan pembiayaan dengan prinsip syariah dalam bentuk modal kerja dalam hal ini adalah pembiayaan dengan prinsip bagi hasil kepada koperasi primer untuk diteruskan kemudian pembiayaan tersebut diteruskan kepada anggotanya. ${ }^{21}$ Selain itu bank syariah dapat bekerja sama dengan lembaga keuangan mikro syariah yang segmentasi pembiayaannya ditujukan memang bagi usaha mikro.

Ketiga, peningkatan kualitas dan kuantitas SDI perbankan syariah. Bagi perbankan syariah, maka pengembangan SDI tidak hanya memerlukan pengetahuan yang luas di bidang perbankan, memahami implementasi prinsip-prinsip syariah di dalam praktiknya, namun juga memiliki komitmen yang kuat untuk menerapkannya secara konsisten. Selain itu pengembangan jaringan kantor maupun lembaga keuangan mikro. Pengembangan jaringan kantor bank syariah sangat diperlukan dalam rangka perluasan jangkauan pelayanan kepada masyarakat. Sebagaimana pada perbankan konvensional yang memiliki jaringan kantor hingga ke pelosok daerah, maka perbankan syariah diharapkan memiliki jumlah jaringan yang luas sehingga akan meningkatkan efisiensi usaha serta meningkatkan kompetisi ke arah peningkatan kualitas pelayanan dan mendorong inovasi produk dan jasa perbankan syariah.

Keempat, meningkatkan pemahaman masyarakat mengenai budaya kejujuran dan produk pembiayaan bank syariah. Perilaku atau perangai masyarakat yang dikhawatirkan oleh perbankan syariah tersebut di dalam sosiologi hukum telah disebutkan. Perilaku tidak jujur masyarakat dalam objek kajian sosiologi hukum disebut dengan behavior, yaitu merupakan kenyataan hukum di masyarakat yang terkadang terjadi tidak sesuai dengan apa yang diharapkan. Dalam Islam, perilaku tersebut disebut dengan akhlak. Akhlak atau sistem perilaku dapat dipengaruhi oleh dua pendekatan, yaitu: ${ }^{22}$ (a) rangsangan, yaitu perilaku manusia terwujud karena adanya dorongan dari suatu keadaan. Pendekatan ini bisa dilakukan dengan cara terjun langsung di masyarakat, dengan memberikan pelatihan-pelatihan mengenai pembukuan atau manajemen keuangan yang baik, melakukan tanya jawab atas prospek usaha yang sedang dijalankan sehingga akan memberikan motivasi kepada para pengusaha tersebut untuk terus mengoptimalkan usaha. (b) Kognitif, yaitu penyampaian informasi yang didasari oleh dalil-dalil yang benar. Misalnya dalil Al-Qur'an dan Hadist. Pendekatan ini dilakukan dengan menggelar diskusi ataupun seminar mengenai pentingnya mencari penghidupan yang lebih baik dengan 
usaha keras disertai kejujuran sebagaimana yang disebutkan di dalam Al-Qur'an dan Hadist.

Solusi lain dalam mengatasi masalah terjadinya kondisi asymmetric information yang menyebabkan pihak bank tidak mengetahui dengan pasti kondisi usaha maupun kondisi keuangan dari mudharib adalah dengan mencantumkannya ke dalam salah satu klausul di dalam akad pembiayaan bank.

Perjanjian kredit bank dan perumusan klausul-klausul di dalamnya sangat tergantung dari kebutuhan calon debitur secara pribadi, dan bank harus dapat mengantisipasinya dengan cepat. $^{23}$ Hal ini berarti mudharib dan shahibul maal merupakan mitra dan tidak ada satu pihak yang dirugikan. Untuk itulah maka perjanjian kredit dibuat dengan sebelumnya dilakukan negosiasi diantara kedua belah pihak. Pihak bank dapat meminta dimasukkannya kondisi asymmetric information ke dalam salah satu klausul, yaitu yang berkaitan dengan penipuan data.

\section{Simpulan}

Pemberdayaan

UMKM melalui pembiayaan dengan prinsip bagi hasil oleh lembaga keuangan syariah di Kota Malang masih terbentur pada risiko yang harus dihadapi. Risiko tersebut berkaitan dengan kesulitan bank sebagai shahibul maal mendapatkan informasi yang akurat mengenai karakter nasabah pengelola (mudharib) dan mengenai usaha yang akan dibiayai pada saat menyeleksi mudharib dan usahanya tersebut. Oleh sebab itu untuk meminimalisir risiko yang ada, bank menerapkan pola executing, yaitu melakukan pembiayaan mudharabah tidak secara langsung kepada UMKM melainkan memberikan pembiayaan tersebut kepada koperasi primer serta Baitul Maal wat Tamwil (BMT).

Pemberdayaan Usaha Mikro Kecil dan Menengah (UMKM) oleh lembaga keuangan syariah di Kota Malang terkendala oleh beberapa hal, misalnya berkaitan dengan prinsip kehati-hatian perbankan sebagaimana yang diamanatkan oleh undang-undang yaitu usaha yang tidak memiliki agunan maka dianggap tidak layak untuk mendapatkan pembiayaan. Kekhawatiran terjadinya asymmetric information yaitu pelaporan jumlah keuntungan yang tidak benar oleh mudharib juga menyebabkan bank sangat berhati-hati dalam memberikan pembiayaan dengan prinsip bagi hasil dalam jumlah yang banyak dan cenderung memberikan pembiayaan dengan prinsip yang lain yaitu jual beli karena dianggap lebih aman. Hal tersebut berkaitan juga dengan keterbatasan Sumber Daya Insani yang dimiliki oleh perbankan syariah. Usaha yang dijalankan oleh mudharib membutuhkan pengawasan oleh mereka yang berkompeten di bidangnya, dan pengawasan inilah yang bisa meminimalisir terjadinya asymmetric information antara shahibul maal dengan mudharib. 
Terhadap kendala yang ada maka para pengusaha UMKM yang tidak bankable dapat menjadi anggota pada suatu koperasi primer dengan salah satu pilihan pembiayaannya adalah pembiayaan dengan prinsip bagi hasil.

\section{DAFTAR PUSTAKA}

\section{Buku}

A.M. Saefuddin, 1984, Studi Sistem Ekonomi

Islam, Media Dakwah, Jakarta.

Adiwarman A. Karim, 2004, Bank Islam:

Analisa Fikih dan Keuangan,

RajaGrafindo Persada, Jakarta.

Adiwarman A. Karim, 2001, Ekonomi Islam,

Suatu Kajian Kontemporer,Gema

Insani Press, Jakarta.

Ahmad Hasan Ridwan, 2004, BMT dan

Bank Islam Instrumen Lembaga

Keuangan Syari`ah, Pustaka Bani

Quraisy, Bandung.

Burhanuddin S., 2011, Hukum Bisnis

Syariah, UII Press, Yogyakarta.

Dinas Koperasi dan Usaha kecil dan Menengah

Kota Malang, 2011, Data statistik

Dinas Koperasi dan Usaha kecil dan

Menengah Kota Malang Tahun 2011,

Malang.

Djoni S. Gazali dan Rachmadi Usman, 2012,

Hukum Perbankan, Sinar Grafika, Jakarta.

Hirsanuddin, 2008, Hukum Perbankan

Syariah di Indonesia, Genta Press,

Yogyakarta.

Johannes Ibrahim, 2004, Bank Sebagai

Lembaga Intermediasi dalam

Hukum Positif, Utomo, Bandung.
Kasmir, 1998, Bank dan Lembaga Keuangan

Lainnya, Rajawali Press, Jakarta.

Lukman Dendawijaya, 2003, Manajemen

Perbankan, Ghalia Indonesia, Bogor.

Muhammad Syafi'i Antonio, 2001, Bank

Syariah: dari Teori ke Praktik, Gema Insani Press, Jakarta.

Nurul Huda dan Mohamad Heykal, 2010, Lembaga Keuangan Islam: Tinjauan

Teoritis dan Praktis, Kencana, Jakarta.

Suhrawardi K. Lubis dan Farid Wajdi, 2012, Hukum Ekonomi Islam, Sinar Grafika, Jakarta.

Suhrawardi K. Lubis, 2004, Hukum Ekonomi

Islam, Sinar Grafika, Jakarta.

Sunarto Zulkifli, 2004, Panduan Praktis

Transaksi Perbankan Syariah, Zikrul

Hakim, Jakarta.

Warkum Sumitro, 1996, Asas-asas

Perbankan Islam dan Lembaga-

lembaga yang terkait, RajaGrafindo

Persada, Jakarta.

Zainuddin Ali, 2008, Sosiologi Hukum, Sinar

Grafika, Jakarta.

\section{Makalah}

Sutan Remy Sjahdeini, 1995, Pencegahan dan

Penanggulangan Kredit Bermasalah, 
Makalah disajikan pada perkuliahan

Magister Hukum Universitas Surabaya.

Naskah Internet

Bank Indonesia, Buku Kajian Akademik

Pemeringkat Kredit bagi Usaha

Mikro Kecil dan Menengah di

Indonesia, www.bi.go.id.

Suara Merdeka, Bank Syariah dan Industri

Kreatif, www.suaramerdeka.com. , Pertumbuhan Perbankan Syariah Belum Optimal, www. suaramerdeka.com.

Republika, Pertumbuhan Perbankan Syariah Belum Optimal, www. republica.co.id.

Kompas, Keterbatasan UKM Dalam Meraih Pembiayaan Bank Syariah, www.kompas.com. 